\title{
THE INFLUENCE OF BENSON RELAXATION TOWARDS THE LEVEL OF ANXIETY IN CERVICAL CANCER PATIENTS IN INPATIENT WARD OF CAMAR III AT GENERAL HOSPITAL OF ARIFIN ACHMAD PEKANBARU 2015
}

\author{
Yenny Safitri \\ Dosen FIK Universitas Pahlawan Tuanku Tambusai, Riau, Indonesia \\ Email: yennysafitri37@yahoo.co.id
}

\begin{abstract}
One of the therapy that can reduce anxiety is Benson relaxation. This therapy will inhibit the activity of the sympathetic nervous which will reduce oxygen consumption by the body and then the muscles are relaxed, causing a feeling of calm and comfortable. This study uses a quasi-experimental research design, with the approach of pretest-posttest design with control group, involving the control group in addition to the experimental group. With the use of accidental sampling technique then set 30 as sample. The measurement of anxiety exerts performed before and after treatment using Ratting Hamilton Anxiety Scale (HARS) the intervention is given for 1 week. The results of statistical tests using independent $t$ test obtained $\mathrm{p}$-value $=0.000$ significant $\mathrm{p}$-value $<0.05$ then Ho is rejected, which means that the influence of Benson relaxation on the level of anxiety in patients with cervical cancer before and after Benson relaxation therapy.
\end{abstract}

Key words: Benson relaxation, anxiety, cervical cancer 


\section{INTRODUCTION}

Cancer is a disease that begins when abnormal cells modified by genetic mutations of Deoxyribo Nucleid Acid (DNA) service. These abnormal cells creates clones and begin to proliferate abnormally, ignoring signals regulate cell growth within the surrounding environment (Smeltzer \& Bare, 2001).

One of the most frequent cancers in women worldwide is cervical cancer. In 2008, cervical cancer ranks at a second after breast cancer. The average incidence of 15 per 100,000 women in the world (Depkes, 2012). Whereas in developing countries, cervical cancer ranks at the first with a prevalence of 30-45 per 100,000 people every year (Emilia, Kusumanto, Hananda, \& Freitag, 2010). According to data from the Hospital Information System of the year (2008, in Depkes 2012), cervical cancer ranks at the second $(10.3 \%)$ in inpatients patients in all hospitals in Indonesia.

According to data from the Medical Record Camar 3 of General Hospital (RSUD) of Pekanbaru. The cases of cervical cancer each year is an increase. There were 113 cases in 2012 and 132 cases in 2011. (Medical Record Camar III, General Hospital of Arifin Achmad, 2012).

Cervical cancer is a cancer that growth from cells of the cervix, cervical cancer can be derived from the cells in the cervix, but can also be grown from cells of the cervix, or both (Nurwijaya, Andrijono, \& Suhaemi, 2010). Cervical cancer is caused by infection with Human Pavilloma Virus (HPV). More than $90 \%$ of cervical cancers types of squamous contain of DNA virus of HPV and $50 \%$ of cervical cancers associated with HPV type 16 (Aziz, Andijono, and Saifuddin, 2006).
At the beginning of cancer, there are no specific signs and symptoms in patients. Signs such as vaginal discharge itching and abnormal vaginal bleeding after sexual activity or blood discharge from the vagina during menstruation are the main complaints of patients suspected of suffering from cervical cancer (Rasjidi, 2007). Besides that, another signs is bleeding that is longer and more during menstruation and bleeding from the vagina after menopause. These things can be found when the cancer has reached stage II or more. In stage III or more, the patient began to experience weight loss, bleeding constantly through the vagina which can cause anemia or anemia, pain in the pelvis, legs, and back, problems urinary because of barriers or the propagation of cancer of the urinary tract or kidneys and bleeding from the urethra or anus (Emilia, Kusumanto, Hananda, \& Freitag, 2010)

Signs and symptoms that occur in patients with cervical cancer also influence emotional disorder of patients. Patients with cancer feel as new threats and diseases that do not exist eventually. Denial, anxiety and acceptance are a normal emotional reaction from the patient and those closest to when faced with a bad diagnosis. Starting from hopeless, no longer seeing a bright light, caused distrust and denial. (Jong, 2004).

A therapy for cervical cancer is usually given in the form of surgery and treatment. Surgery such as hysterectomy and radiation. While the medication treatment is in the form of chemotherapy (Benson \& Pernoli, 2008)

Pharmacological treatment with surgery and medication treatment can be a particular burden and a threat. Reactions such as helplessness, hopelessness, anxiety, 
depressive or revolted can dominate so that the effect of additional symptoms and complications of the more disturbing (Jong, 2004)

Severe anxiety will affect the human nervous system work that is hypothalamus which controls and regulates the autonomic nervous system. In the condition of anxiety, the nervous system will issue a noreepinefrin through the secretion of the nerve endings that are directly related to the tip of the organ in targeted. As a result, increased heart rate, peripheral vasoconstriction occurs resulting in an increase in blood pressure. An increase in blood glucose, the pupil will dilate, and mental activity will increase. Sense of preparedness to be larger (Smeltzer \& Bare, 2001).

One of the therapy that can reduce anxiety is Benson relaxation Benson (Djauzi, in Green \& Setyowati, 2004). Benson Relaxation is a relaxation technique combined with the beliefs owned by the patient. Benson and Proctor (2000) explain that Benson relaxation will inhibit the activity of the sympathetic nerves which can reduce oxygen consumption by the body and then the muscles are relaxed, causing a feeling of calm and comfortable.

According to the research results of Purwanti et al (2012) says there is no difference in blood pressure before and after the Benson relaxation therapy. Relaxation therapy could reduce levels of cortisol which is a stress hormone that contribute to high blood pressure. In addition, Benson relaxation can also effective to reduce pain in addition using analgesic therapy. This is in line with Datak (2008), which conducts research on the effectiveness of Benson relaxation against post-surgical pain in patients with transurethral resection (TUR) of the prostate. This method indicates that the combination of relaxation Benson and therapeutic analgesic more effective to reduce pain after surgery in patients TUR Prostate compared to only analgesic therapy.

Based on preliminary studies conducted on June $29^{\text {th }} 2015$ at General Hospital of Arifin Achmad Pekanbaru which is the referral hospital in Riau provinces obtained interviews in 3 patients suffering from cervical cancer, two people experience severe anxiety, and one person having anxiety being. One patient said felt increased anxiety at the time to perform radiotherapy.

Based on the phenomenon, the researchers feel that the anxiety in patients with cervical cancer needs to be addressed. Researchers try to give Benson relaxation therapy is to know the influence of Benson relaxation on the level of anxiety in patients with cervical cancer.

\section{METHODOLOGY}

The research is a quantitative using quasi-experimental research design, with the approach of pretest-posttest design with control group. The purpose of the research is to reveal a causal relationship by involving the control group in addition to the experimental group (Nursalam, 2003). The study was conducted at General Hospital of Arifin Achmad in inpatients ward Camar 3. The research conducted on September 2015. Analysis of the data used univariate and bivariate test with sample $\mathrm{T}$ Test Dependent and Independent sample $t$ test. The data collection in this research is using the anxiety scale sheet Ratting Hamilton Anxiety Scale (HARS). HARS scale is used as observation sheet anxiety 
cervical cancer patients who fulfill the criteria.

\section{RESULTS}

\section{Results of the research}

Table 1

The distribution of respondents based on age characteristics

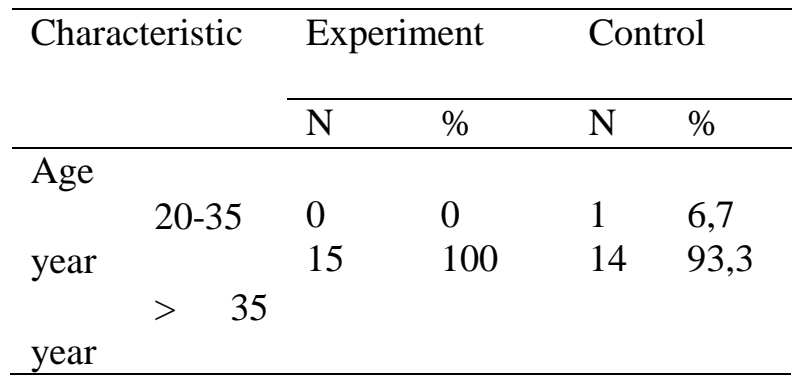

Table 1 shows that the highest age groups of respondents were in the age group> 35 years of which $29(96.6 \%)$.

Table 2

The average score of anxiety in the experimental group before and after the relaxation Benson

\begin{tabular}{llll}
\hline Exsperiment & Mean & SD & $\mathrm{P}$ \\
\hline - Pretest & 24,13 & 7,060 & 0,000 \\
- Posttest & 15,27 & 6,330 & \\
\hline
\end{tabular}

Based on the table 2, the mean score of anxiety in the experimental group was 24.13 with a standard deviation as much 7.060. After given Benson relaxation obtained an average score of anxiety was 15.27 with a standard deviation of 6.330 . Statistical test results obtained value of 0,000 , it can be concluded that there are significant differences between anxiety before and after treatment.

Table 3
The average anxiety scores in control group before and after treatment without given

\begin{tabular}{llll}
\hline Kontrol & Mean & SD & P \\
\hline - Pretest & 21,80 & 7,729 & 0,156 \\
- Posttest & 22,40 & 8,626 & \\
\hline
\end{tabular}

Based on table 3 , the mean score of anxiety before with no treatment given is 21.80 with a standard deviation of 7.729 . After a given treatment without obtained mean score of anxiety are 22.40 with a standard deviation of 8.626. Statistical test results obtained value of 0.156 , it can be concluded there was no significant difference between anxiety before and after no treatment is given.

Table 4

The difference of average score of anxiety in the experimental group after given Benson relaxation and without giving treatment in the control group

\begin{tabular}{llll}
\hline Groups & Mean & SD & P \\
\hline Experiment & 15,27 & 6,330 & 0,026 \\
Control & 22,40 & 8,626 & \\
\hline
\end{tabular}

Based on table 4, the mean score of anxiety after a given Benson Relaxation in the experimental group was 15.27 with a standard deviation of 6.330 and 22.40 in the control group with no treatment given by a standard deviation of 8.626. Statistical test results obtained value of 0,026 , it can be concluded that Benson Relaxation is more effective in reducing anxiety than no treatment given.

\section{DISCUSSION}

1. Age of respondent

Based on the results, many patients who suffer cervical cancer are in the range> 35 years as many as 29 people $(96.6 \%)$. This is in line with 
Sukaca (2009) that women suffering from cervical cancer mostly aged $>35$ years. At the age of 35-55 years have a 2-3-fold risk of developing cervical cancer. The older the person will experience deterioration process, the process does not occur on a single device but on the whole organ. All parts of the body in decline, so that the elderly more likely to fall ill, or susceptible to infection.

2. The average score of anxiety before and after conducting Benson relaxation in the experimental group.

Results of statistical test by using dependent t-test, the mean score of anxiety in the experimental group before being given Benson relaxation is 24.13 , while the mean score of anxiety in the experimental group after given relaxation was 15.27. Based on these results, it can be concluded that a decline in the mean score of anxiety in the experimental group after given the relaxation. It can be concluded that there is significant influence between anxiety in the experimental group before and after Benson relaxation.

This is in line with the statement of Benson and Proctor (2000) that developed the Benson relaxation of the relaxation response method which involves belief factors. The patient conducting the relaxation by repeating a word or phrase that is in accordance with the beliefs of the patient that can inhibit noxious impulses to the control system descending (gate control theory) and improve control of pain.

3. The average anxiety scores of cervical cancer patients before and after without given a treatment in the control group.

Based on the statistical test using a dependent t-test, the mean score of anxiety before without given treatment in the control group was 21.80, while the mean score of anxiety after without given treatment was 22.40. Based on these results it can be concluded that an increase in the mean scores of anxiety in the control group after without given treatment. It can be concluded there was no significant influence of anxiety in the control group before and after without given treatment.

This was probably caused by chronic diseases factor and physical health experienced by respondents so it can increase anxiety (Vide Beck, 2008). According to Tanjung (2012), there were several internal and external factors that affect the patient's anxiety of cervical cancer includes potential factors stressors, maturity, education and economic status, physical state, personality type and factor family support, social support, and access information. The results showed that the greatest internal factors causing anxiety is the maturity factor as much as $(57.1 \%)$. While an external factors is a social support factor as much as $(14.2 \%)$.

4. The influence of Benson relaxation on reducing anxiety in the experimental group and the control group

Based on the results of statistical tests using independent t-test obtained $\mathrm{p}$ value of 0.000 means the value of anxiety is $p$ value $<0.05$ then Ho is rejected, which means that anxiety in patients with cervical cancer by using Benson relaxation is more effective to reduce anxiety.

This is in line with Purwati et al in (2012) regarding the differences in blood pressure before and after the 
Benson relaxation therapy. The results showed there is a difference in blood pressure before and after conducting Benson relaxation in hypertensive patients. View from the results of the analysis of paired samples T-test was obtained $p$-value of $0.000<0.05$.it can concluded that Benson relaxation is able to reduce levels of the stress of hormone cortisol which contribute significantly to high blood pressure.

The other results also prove that Benson relaxation is also effective to reduce pain in addition to using analgesic therapy. Research conducted by Datak (2008) concerning the effectiveness of Benson relaxation against post-surgical pain in patients with transurethral resection (TUR) of the prostate. The results showed that the combination of Benson relaxation and analgesic therapy is more effective to reduce post-surgical pain in patients with prostate TUR compared with only analgesic therapy.

According to Smeltzer \& Bare (2001) in their theory said that the stress response starts from the hypothalamus secrete corticotrophinreleasing factor, which stimulates the anterior pituitary to produce adenocorticotropic hormone (ACTH). Later, ACTH stimulates the anterior pituitary to produce glucocorticoids, especially cortisol. Mental stress can increase cortisol. Thus stimulate the sympathetic nervous responses such as increasing of heart rate, blood pressure, blood glucose, the pupil will dilate and increasing of mental activity. Subjectively, person will feel cold feet, skin and moist hands, shivering, palpitations and spasms in the stomach. If an individual conduct the relaxation when he suffered a tension or anxiety, the physiological reactions of individuals perceived will reduce.

The results reported that respondents who have been doing Benson relaxation for about 15 minutes feel experiencing a sense of calm and comfortable so that anxiety is reduced. This is because of Benson relaxation can inhibit the activity of the sympathetic nerves that lead to a reduction of the oxygen consumption by the body and then the muscles are relaxed, causing a feeling of calm and comfortable. Moreover, Benson relaxation focusing on certain words or phrases spoken repeatedly with a regular rhythm and with the attitude that surrenders to God Almighty according patients so that the anxiety can be reduced (Benson and Proctor, 2000).

Thus, in this research we can conclude that the administration of Benson relaxation can reduce anxiety in patients with cervical cancer.

\section{CONCLUSION}

The results showed that the characteristics of respondents based on age at most widely around > 35 years are 29 people $(96.6 \%)$. Results of statistical test by using t-test $\mathrm{p}$ dependent on experiment obtained group $(0,000)<\alpha(0.05)$. It can be concluded that there are significant differences between anxiety in the experimental group before and after Benson Relaxation. In control group, there was no significant difference between anxiety in the control group before and after without given Benson Relaxation.

The results of statistical tests using independent $\mathrm{t}$ test was obtained $\mathrm{p}(0.000)$ $<\alpha(0.05)$. It can be concluded that anxiety 
in patients with cervical cancer by using Benson Relaxation is more effective to reduce anxiety.

\section{SGGESTIONS}

1. Hospitals

Benson relaxation interventions proven to be effective to reduce anxiety towards cervical cancer, which is expected for consideration and use by institutions of midwifery services as one of the standard operating procedures (SOP) in patients who suffer anxiety either cervical cancer or suffering from other diseases. It is also expected to provide a special room that is quiet, not noisy for patients with advanced disease in particular, to the creation of a quiet room in order to get a comfortable atmosphere for patients.

2. Educational institution

The institutions can make Benson relaxation theory as one of the lecture material and briefing for midwives and nurses.

3. Patients with cervical cancer and family

Cervical cancer patients should always think positive and be able to conduct independently Benson relaxation to avoid excessive anxiety.

4. Next researcher

Next researchers then expected to classify patients more specifically according to the level the stage prior to further investigate, and can conduct the research by using longer period, and using a cohort study design.

\section{BIBLIOGRAPHY}

Benson, R. C \& Pernoll, M. L. (2008). Buku saku obstetri \& ginekologi. edisi 9. Jakarta: EGC.

Benson, H \& Proctor, W. (2000). Dasardasar respons relaksasi. Bandung: Kaifa.

Datak, G. (2008). Efektivitas relaksasi Benson terhadap nyeri pasca bedah pada pasien transurethral resection of the prostate di Rumah Sakit Umum Fatmawati Jakarta. Tesis. Program Pascasarjana Kekhususan Keperawatan Medikal Bedah Fakultas Ilmu Keperawatan Universitas Indonesia.

Depkes (2012). Gerakan perempuan melawan kanker serviks. Diperoleh 20 November 2012 dari http://www.depkes.go.id/index.php/ berita/press-release/1668-gerakanperempuan-melawan-kankerserviks.

Emilia, O., Kusumanto, A., Hananda, I.P.Y., dan Freitag, H. (2010). Bebas ancaman kanker serviks. Yogyakarta: Media Pressindo.

Green, C. W.,\& Setyowati, H. (2004). Seri buku kecil terapi alternatif. Yogyakarta: Yayasan Spritia

Jong, W. D. (2004). Kanker, apakah itu? pengobatan, harapan hidup, dan dukungan keluarga. Jakarta: Arcan

Purwati, dkk. (2010). Perbedaan tekanan darah sebelum dan sesudah terapi relaksasi Benson pada pasien hipertensi. Diperoleh tanggal 17 
November 2012 dari
http://ejournal stikestelogorejo ac.id

Rasjidi, I. (2007). Panduan penatalaksanaan kanker ginekologi berdasarkan evidence base. Jakarta: EGC.

Smeltzer, S.C., \& Bare, B.G. (2001). Buku ajaran keperawatan medikal-bedah brunner \& suddarth $\left(8^{\text {th }} e d\right)$. Jakarta: EGC.
Sukaca, B.E. (2009). Cara cerdas menghadapi kanker serviks /genius. Yogyakarta: Genius.

Tanjung, M.U \& Nasution, M.L. (2012). Faktor internal dan eksternal kecemasan pada pasien kanker serviks di RSUP H.Adam Malik Medan. Diperoleh tanggal 01 Februari 2013 dari http://jurnal.usu.ac.id

Videbeck, S. L. (2008). Buku ajar keperawatan jiwa. Jakarta: EGC. 